\title{
Trace Elements in Consumer Plants
}

\author{
Józefa Wiater ${ }^{1 *}$, Ada Wojciula² \\ 1 Białystok University of Technology, Department of Environmental Engineering Technology and Systems, \\ ul. Wiejska 45E, 15-351 Białystok, Poland \\ 2 A graduate of the Bialystok University of Technology, ul. Wiejska 45E, 15-351 Białystok, Poland \\ * Corresponding author's e-mail: j.wiater@pb.edu.pl
}

\begin{abstract}
The aim of this study was to estimate the content of trace elements $(\mathrm{Zn}, \mathrm{Cu}, \mathrm{Cr}, \mathrm{Cd}, \mathrm{Pb})$ in soils and consumer plants grown under and without the influence of traffic. The species such as lettuce, raspberry, beetroot, apple, carrot, chives and onion were selected for the study. The samples were mineralized and the heavy metal content in plants and soils was determined by means of atomic absorption spectrometry. The content of heavy metals in the soil from municipal allotments was higher than in the soil from the Saniki Colony. For both samples, the permissible soil content was not exceeded. The amount of trace elements in plants varied depending on species, but the place of vegetables and fruits origin was also important. Most of trace elements occurred in larger amounts in the plants from allotments, and in smaller amounts in the plants from Saniki Colony.
\end{abstract}

Keywords: heavy metals, vegetables, fruits, bioaccumulation, soils

\section{INTRODUCTION}

Vegetables and fruits are an integral part of human nutrition. They are rich, among others, in valuable macroelements. They enable a plant to grow, develop as well as provide the living organisms with essential ingredients to ensure their proper functioning. First of all, a plant without adequate nutrients is not able to complete the development cycle, and action of a specific ingredient can not be replaced by any other [Gorlach and Mazur, 2001]. The role of macroelements is therefore very important, and each of them is responsible for specific functions. Above all, they fulfill the building and physiological functions. Among them, nitrogen, phosphorus, sulfur, potassium, calcium, magnesium, carbon, hydrogen and oxygen stand out [Wierzbicka and Trawczyński, 2011]. Consuming large amounts of vegetables and fruits is not only a fashion, but also has proven positive effects on human body functioning. Vegetables and fruits are easy to buy in bazaars and supermarkets, but they are often grown in allotments. Those places are usually located in city centers, and this means that the plants are exposed to the anthropogenic factors that are source of heavy metals, such as industry, energy and automotive development. This causes interference in many elements of biocenosis and their bioaccumulation in the food chain [Hławiczka, 2008]. The results of studies on the content of trace elements are very important because they form the basis for assessing the human health threat degree [Kabata-Pendias and Pendias, 1999]. The chemical analysis of plants allows determining the content of trace elements and making qualitative assessment. The purpose of this study was to determine the content of trace elements in soils and plants cultivated under the conditions of traffic and without the influence of these conditions. 


\section{RESEARCH AREA AND METHODOLOGY}

The soil and cultivated plants samples were collected from two plots located in Podlasie Voivodship, and more specifically from the macroregion of Białostocka Upland. Selection of these points was dictated by their location. Many factors were analyzed and the areas that were located in completely different places with different conditions were selected. First of them was in Saniki Colony (a quiet village colony). The area is not industrialized, mostly covered by arable land, pastures, meadows, gardens and orchards, as well as few farms with residential buildings. The area is not exposed to the anthropogenic impact due to its location and surroundings. The soil samples from Saniki Colony were defined as typical black soil, with a poor agricultural and cereal fodder complex (class IVa, IVb), with grain composition with predominance of sands. The advantage of these soils is a relatively well-developed humus level. The second point involved the allotments located in city center, with large impact of communication and small industrial plants. Soils are classified as typical brown eutrophic with poor agricultural rye complex (class IVb, V), which are composed of light loamy sands or clays. Despite better granulometric composition than the soil in Saniki Colony, these soils can be permanently or periodically too dry. In addition, due to the presence of surface ochric level, the amount of organic matter is small. The research was based on the soil samples taken from both points and consumer plants grown on them. These were: chives, carrots, beets, lettuce, onions, raspberries and apples. The content of trace elements $(\mathrm{Cr}, \mathrm{Pb}$, $\mathrm{Cu}, \mathrm{Zn}, \mathrm{Cd}$ ) was determined in them and bioaccumulation coefficients were calculated. The samples were mineralized in a Milestone microwave digester, model ETHOS EASY, in aqua regia. The rlements were determined using the ASA technique, by means of an atomic absorption spectrometer from Thermo Scientific, model iCE 3500.

\section{RESULTS AND DISCUSSION}

The content of heavy metals in the soil exposed mainly to traffic was higher than in soil not subjected to such influences. The zinc and chromium content in the soil from allotments was more than twice higher than in the soil not exposed to traffic. However, the copper content was four times higher in the soil from allotments than in the soil from Saniki Colony. The cadmium content was almost twice as high in the soil subjected to mainly traffic impact as in the soil from Saniki Colony. Moreover, the lead content was slightly higher than in the soil from Sanik (Table 1). For both samples, the standards set out in the Regulation of the Minister of the Environment from 2016 on method of assessment of ground surface pollution were not exceeded [Regulation, 2016]. According to Filip [2003], the zinc limit for light soils intended for all horticultural and agricultural plants (including children's vegetable plants) is $70 \mathrm{mg} / \mathrm{kg}$ dry matter. The content of this element in the soil from allotments was higher, and it was $72.2 \mathrm{mg} / \mathrm{kg}$ dry matter. In the case of cadmium, there was similar relationship, because according to Filip [2003], the maximum content for soils on which plants are grown for consumption is 0.50 $\mathrm{mg} / \mathrm{kg}$, and in soil from allotments $0.76 \mathrm{mg} / \mathrm{kg}$ of this metal was found.

The content of analyzed metals varied depending on sampling place and plant species (Table 1). In most of the analyzed samples, more zinc occurred in the case of allotments than the

Table 1. The content of trace elements in soils and plants

\begin{tabular}{|c|c|c|c|c|c|c|c|c|c|c|}
\hline \multirow{3}{*}{$\begin{array}{r}\begin{array}{r}\text { Trace } \\
\text { element }\end{array} \\
\text { Soil/ } \\
\text { plant }\end{array}$} & \multicolumn{10}{|c|}{ Content (mg/kg d.m.) } \\
\hline & \multicolumn{2}{|r|}{$\mathrm{Zn}$} & \multicolumn{2}{|r|}{$\mathrm{Cu}$} & \multicolumn{2}{|r|}{$\mathrm{Cr}$} & \multicolumn{2}{|r|}{$\mathrm{Cd}$} & \multicolumn{2}{|r|}{$\mathrm{Pb}$} \\
\hline & $\begin{array}{l}\text { Saniki } \\
\text { Colony }\end{array}$ & $\begin{array}{l}\text { allotments } \\
\text { in Białystok }\end{array}$ & $\begin{array}{l}\text { Saniki } \\
\text { Colony }\end{array}$ & $\begin{array}{l}\text { allotments } \\
\text { in Białystok }\end{array}$ & $\begin{array}{l}\text { Saniki } \\
\text { Colony }\end{array}$ & $\begin{array}{c}\text { allotments } \\
\text { in Białystok }\end{array}$ & $\begin{array}{l}\text { Saniki } \\
\text { Colony }\end{array}$ & $\begin{array}{c}\text { allotments } \\
\text { in Białystok }\end{array}$ & $\begin{array}{l}\text { Saniki } \\
\text { Colony }\end{array}$ & $\begin{array}{l}\text { allotments } \\
\text { in Białystok }\end{array}$ \\
\hline Soil & 35.3 & 72.2 & 4.4 & 16.8 & 9.2 & 22.0 & 0.43 & 0.76 & 12.8 & 17.5 \\
\hline Lettuce & 22.3 & 22.5 & 1.3 & 3.1 & 0.1 & 1.1 & 1.50 & 0.99 & 6.0 & 6.5 \\
\hline Raspberry & 17.2 & 16.5 & 2.6 & 2.7 & 0.2 & 2.0 & 0.49 & 0.80 & 7.0 & 6.5 \\
\hline Beetroot & 22.3 & 81.7 & 2.9 & 11.1 & 0.7 & 2.3 & 2.06 & 1.34 & 6.6 & 6.4 \\
\hline Apple & 5.5 & 1.3 & 37.1 & 1.1 & 0.7 & 1.2 & 0.49 & 1.47 & 6.1 & 6.1 \\
\hline Carrot & 11.7 & 61.9 & 1.7 & 7.3 & 0.5 & 1.6 & 1.51 & 3.50 & 6.3 & 6.4 \\
\hline Chive & 40.1 & 77.2 & 4.4 & 8.6 & 0.9 & 1.8 & 0.93 & 1.47 & 4.9 & 5.5 \\
\hline Onion & 18.5 & 42.6 & 3.1 & 2.8 & 0.5 & 2.4 & 0.88 & 1.43 & 7.0 & 5.6 \\
\hline
\end{tabular}


samples taken on a plot outside the city. Zinc was found in plants in varying amounts because its uptake depends on species and variety [Baran and Jasiewicz, 2009]. Usually, $30 \mathrm{mg} \mathrm{Zn/kg}$ dry matter is sufficient for physiological needs, but larger quantities are not always immediately toxic. In some species it is only at $100 \mathrm{mg} / \mathrm{kg}$ of dry matter that a decrease in yield was observed. The greatest amount of zinc was found in beets from gardens in Bialystok $(81.7 \mathrm{mg} / \mathrm{kg}$ dry matter). High content was also observed in chive $(77,2 \mathrm{mg} / \mathrm{kg}$ dry matter), and it should be noted that this plant is sensitive to the effects of toxic metals. Symptoms of excess of this trace element may be chlorosis and necrosis of leaves and slow growth of these organs, but also roots. During the harvest, chives were low and did not have full green color. The lowest content of studied element was found in the apples from both plots, 1.3 $\mathrm{mg} / \mathrm{kg}$ dry matter in municipal garden, while 5.5 $\mathrm{mg} / \mathrm{kg}$ dry matter in Saniki Colony. Low amount of trace element in fruits from both places was probably due to the high content of phosphorus in them, and high content of phosphorus limits the intake of zinc. As mentioned above, the average demand for zinc in most plants is about $30 \mathrm{mg}$ / $\mathrm{kg}$ dry matter, whereas for apples it is lower. The average content of this trace element for apples is about $0.2-0.5 \mathrm{mg} / \mathrm{kg}$ dry matter [Jędrzejczak, 2002; Zdrojewicz et al., 2015].

Among all examined plants, the copper content in the apples from Saniki Colony stands out the most and it reached $37.1 \mathrm{mg} / \mathrm{kg}$ dry matter. Sensitive plants expierience negative impact of copper already at $15-20 \mathrm{mg} / \mathrm{kg}$ dry matter, while for others it is $30-100 \mathrm{mg} / \mathrm{kg}$ dry matter. A short conversation was held with the owner of the neighboring field and it turned out that the grain near the growing apple trees was treated with a fungicidal plant protection product called Microplan Zboża. Therefore, this result probably came from the presence of this preparation on fruit. Spraying ingredients can easily penetrate through epidermis or leaf stomata [Harasimiuk, 2006]. In the apples from Białystok, the amount of copper was significantly lower and amounted to $1.1 \mathrm{mg} /$ $\mathrm{kg}$ dry matter, which is also generally the lowest zinc content among all samples. In addition, the results varied depending on species, but with a predominance of copper in the plants collected in city gardens.

The plants growing in allotment garden in Bialystok contained more chromium than the plants from Saniki Colony. This may be due to, among others, high traffic on city roads. KabataPendias and Pendias (1999) reports that for sensitive plants occurrence of element in amount of 1-2 mg/kg dry matter can be toxic and can reduce yields. Lettuce and chives, classified as sensitive species, contained 1.1 and $1.8 \mathrm{mg} / \mathrm{kg}$ dry matter of this metal. Onions $(2.4 \mathrm{mg} / \mathrm{kg}$ dry matter) and beetroot $(2.3 \mathrm{mg} / \mathrm{kg}$ dry matter $)$ contained most of this element. These vegetables are moderately sensitive to heavy metals, so they usually tolerate the chromium content up to $8 \mathrm{mg} / \mathrm{kg}$ dry matter [Kabata-Pendias, Pendias, 1999]. The lowest content of all studied plants was observed in the lettuce from Saniki Colony and amounted to 0.1 $\mathrm{mg} / \mathrm{kg}$ dry matter. This is not a deficiency, because chromium is not an essential element for plant development.

Usually, the cadmium content for the abovegroud parts of plants is $0.05-0.2 \mathrm{mg} / \mathrm{kg}$ dry matter. Among the studied plants, the above-groud parts were obtained from lettuce, raspberries, apples and chives. Each of these species had a higher cadmium content than $0.2 \mathrm{mg} / \mathrm{kg}$ dry matter. Exceeding these values does not mean phytotoxic effect of this element. For sensitive plants, the negative effect begins only at $5-10 \mathrm{mg} / \mathrm{kg}$ dry matter, while for more resistant species it is 10$30 \mathrm{mg} / \mathrm{kg}$ dry matter [Kabata-Pendias, 2000]. Although the obtained contents do not indicate toxic effects on plant, they may pose threat to humans. According to Commission Regulation (EU) No. 420/2011 of April 29, 2011, the cadmium content in each tested plant was exceeded. The maximum permissible standard is $0.20 \mathrm{mg} / \mathrm{kg}$ [Regulation, 2011]. The carrot from allotments located in Bialystok contained the most of this element. It is root vegetable that draws cadmium particularly easily [Majewska and Czeczot, 2010; Kabata-Pendias, 2000]. It is worth paying attention to the relationship, which indicates the higher content of this metal in most plants from allotments. Lettuce and beetroot are exceptions. In Saniki Colony, its quantity in these vegetables was higher than in the gardens in Białystok. The raspberries and apples from rural area contained the least cadmium (0.49 $\mathrm{mg} / \mathrm{kg}$ dry matter). Among trace elements determined in the presented study, cadmium has the highest bioaccumulation coefficients. First of all, for each plant the value exceeded 1 , which means that plants had higher metal contents than soil. The observations made by the FAO International Program showed that the amount of cadmium in 
cereal plants is directly proportional to its amount in soil, as such relationships occurred in as many as 30 countries [Kabata-Pendias, 2000]. For consumer plants, similar conclusion can also be drawn in the conducted studies, as for 7 out of 14 species bioaccumulation factor was about 1 and did not exceed the value of 2 .

In all studied vegetables and fruits, lead occurred to a very similar extent and generally no higher content was found in plants from Bialystok. The lowest content occurred in the chive of allotments from the city, while the highest - in the onions from Saniki Colony. The difference was about $1.5 \mathrm{mg} / \mathrm{kg}$ dry matter. Kabata-Pendias states that for areas not affected by direct pollution, vegetables and fruits usually contain up to $3 \mathrm{mg} \mathrm{Pb} / \mathrm{kg}$ dry matter [Kabata-Pendias, Pendias, 1999]. In addition, the author gives the average content of this metal for the examples of species growing in Poland. For beetroots it is $0.7-2 \mathrm{mg} /$ $\mathrm{kg}$ dry matter, for lettuce $0.7-3.6 \mathrm{mg} / \mathrm{kg}$ dry matter, for carrots $0.5-3 \mathrm{mg} / \mathrm{kg}$ dry matter, and for onions $1.1-2 \mathrm{mg} / \mathrm{kg}$ dry matter [Kabata-Pendias, Pendias, 1999]. Lead in all analyzed plants (from Saniki Colony and from Białystok) exceeds the content given by Kabata-Pendias. It is worth emphasizing that the toxic effects on plant often occur already at $5 \mathrm{mg} \mathrm{Pb} / \mathrm{kg}$ dry matter. The emissions from fuel combustion, industrial emissions and coal burning houses could have an impact on the increased content of this metal in city. In rural area, lead sources could include the phosphorus fertilizers applied to fields by farmers.

The bioaccumulation coefficients in the studied plants were below 1 in most samples (Table 2). The uptake of metals by plant roots is proportional to its content in surface soil layers. The more a given element in soil, the greater the content in vegetables or fruits. The level of bioacumulation coefficients in the examined vegetables and fruits proves that they can also be taken by transcript, which is particularly evident in the case of cadmium. Bioaccumulation coefficients also depend on individual characteristics of species and forms of metals that occur in soil. Metals may be present in soil as insoluble complexes, but plant roots may secrete the compounds that release these trace elements. Then they are also transported with water to plants [Ociepa-Kubicka, 2012].

\section{CONCLUSION}

The study showed the differences in the content of trace elements in soils depending on their place of origin. The soils from municipal allotments contained more heavy metals than the soils from the Saniki colony. This is influenced by the anthropogenic impact, primarily developed transport and road traffic. Although none of the samples showed elements in excessive quantities determined in Regulation of the Minister of the Environment of 2016 [Regulation, 2016], allotments are located in a place of continuous exposure to heavy metals from traffic. Metals, together with dust, are transported to soil and increasingly infiltrate into vegetables and fruits. According to Filip (2013), light soils containing from $0.5 \mathrm{mg} / \mathrm{kg}$ of cadmium and from $70 \mathrm{mg} / \mathrm{kg}$ of zinc should not grow the vegetables intended for children. The results of research showed that the soils of allotments contained higher amounts of these elements. Therefore, the allotments located in city centers should be excluded from cultivation of consumer plants and used for recreational purposes.

The content of microelements in vegetables and fruits was dependent on the amount of these

Table 2. Bioaccumulation coefficients

\begin{tabular}{|c|c|c|c|c|c|c|c|c|c|c|}
\hline Trace & \multicolumn{10}{|c|}{ Content (mg/kg d.m.) } \\
\hline & \multicolumn{2}{|r|}{$\mathrm{Zn}$} & \multicolumn{2}{|r|}{$\mathrm{Cu}$} & \multicolumn{2}{|r|}{$\mathrm{Cr}$} & \multicolumn{2}{|r|}{$\mathrm{Cd}$} & \multicolumn{2}{|r|}{$\mathrm{Pb}$} \\
\hline $\begin{array}{l}\text { Soil/ } \\
\text { plant }\end{array}$ & $\begin{array}{l}\text { Saniki } \\
\text { Colony }\end{array}$ & $\begin{array}{l}\text { allotments } \\
\text { in Białystok }\end{array}$ & $\begin{array}{l}\text { Saniki } \\
\text { Colony }\end{array}$ & $\begin{array}{l}\text { allotments } \\
\text { in Białystok }\end{array}$ & $\begin{array}{l}\text { Saniki } \\
\text { Colony }\end{array}$ & $\begin{array}{l}\text { allotments } \\
\text { in Białystok }\end{array}$ & $\begin{array}{l}\text { Saniki } \\
\text { Colony }\end{array}$ & $\begin{array}{l}\text { allotments } \\
\text { in Białystok }\end{array}$ & $\begin{array}{l}\text { Saniki } \\
\text { Colony }\end{array}$ & $\begin{array}{l}\text { allotments } \\
\text { in Białystok }\end{array}$ \\
\hline Lettuce & 0.63 & 0.31 & 0.29 & 0.19 & 0.01 & 0.05 & 3.49 & 1.30 & 0.47 & 0.37 \\
\hline Raspberry & 0.49 & 0.23 & 0.60 & 0.16 & 0.02 & 0.09 & 1.14 & 1.05 & 0.55 & 0.37 \\
\hline Beetroot & 0.63 & 1.13 & 0.67 & 0.66 & 0.07 & 0.11 & 4.79 & 1.76 & 0.52 & 0.36 \\
\hline Apple & 0.16 & 0.02 & 8.48 & 0.07 & 0.08 & 0.06 & 1.14 & 1.93 & 0.48 & 0.35 \\
\hline Carrot & 0.33 & 0.86 & 0.38 & 0.43 & 0.06 & 0.07 & 3.51 & 4.61 & 0.49 & 0.36 \\
\hline Chive & 1.01 & 1.07 & 1.00 & 0.50 & 0.10 & 0.08 & 0.46 & 1.93 & 0.40 & 0.32 \\
\hline Onion & 0.52 & 0.59 & 0.71 & 0.17 & 0.06 & 0.11 & 2.05 & 1.88 & 0.55 & 0.32 \\
\hline
\end{tabular}


elements in soil. The greater content in soil, the greater concentration in consumer plants. This is confirmed by the values of bioaccumulation coefficients, presented in Table 2. However, apart from this factor, the plant species had a large impact on the content of elements. Individual species characteristics and type of root system determined diverse metal content in vegetables and fruits. The content of most trace elements was higher in the consumer plants from allotments in Bialystok, and in smaller amounts in plants from Saniki Colony. The Lettuce and chive grown on soil in city were found to have toxic amount of chromium that can affect the physiological functions of these vegetables. The apples collected from a plot in Cologne Saniki also contained a high copper content, which was caused by the application of foliar fertilizer supplying grain to neighboring field. All studied samples showed excessive cadmium (exceeding the standards set in EU Commission Regulation of 2011) and lead content.

\section{REFERENCES}

1. Baran A., Jasiewicz Cz. 2009. Toxic zinc and cadmium content in soil for various plant species. Environmental Protection and Natural Resources, Institute of Environmental Protection, Warsaw, No. 40, 157-164 (in Polish).

2. Filipek T. (ed.). 2003. Fundamentals and effects of agroecosystem chemization. Publishing House of the Agricultural University in Lublin, Lublin (in Polish).

3. Gorlach E., Mazur T. 2001. Agricultural chemistry: nutrition basics and principles of plant fertilization. PWN Scientific Publisher, Warsaw (in Polish).
4. Harasimiuk A. 2006. Bioaccumulation of elements in arable crops and soils. University of Warsaw Publishing House, Warsaw (in Polish).

5. Jędrzejczak R. 2002. Zinc in food of plant origin. Zinc in the environment - ecological and methodological problems. Scientific Notebooks of the „People and Environment” Committee of the Polish Academy of Sciences, 445-455 (in Polish).

6. Kabata-Pendias A. 2000. Biogeochemistry of Cadmium. Cadmium in the environment - ecological and methodological problems. Scientific Papers of the „Man and Environment” Committee of the Polish Academy of Sciences, 17-24 (in Polish).

7. Kabata-Pendias A., Pendias H. 1999. Biogeochemistry of trace elements. PWN Scientific Publisher, Warsaw (in Polish).

8. Majewska M., Czeczot. 2010. Cadmium - threat and health effects. Polish Pharmacy, Warsaw Medical University, 66(4), 243-250 (in Polish).

9. Ociepa-Kubicka A., Ociepa E. 2012. Toxic effects of heavy metals on plants, animals and people. Częstochowa University of Technology, Częstochowa, 15(2), 169-180 (in Polish).

10. Commission Regulation (EU) No 420/2011 of 29 April 2011 amending Regulation(EC) No 1881/2006 setting maximum levels for certain contaminants in foodstuffs (in Polish).

11. Ordinance of the Minister of the Environment of September 1, 2016 on the method of conducting an assessment of ground surface pollution (in Polish).

12. Wierzbicka A., Trawczyński C. 2011. Impact of irrigation and soil microorganisms on the content of macro and microelements in organic potato tubers. Plant Breeding and Acclimatization Institute - National Research Institute, Jadwisin (in Polish).

13. Zdrojewicz Z., Cabała K., Pypno D., Bugaj B. 2015. Eat apples - you will be healthier. Family Medicine, Volume 18, Issue 3, Medical University of Piastów Śląskich, Wroclaw, 131-136 (in Polish). 